\title{
$5 '-3$ '-UTR interactions regulate p53 mRNA translation and provide a target for modulating p53 induction after DNA damage
}

\author{
Jing Chen and Michael B. Kastan ${ }^{1}$ \\ Department of Oncology, St. Jude Children's Research Hospital, Memphis, Tennessee 38105, USA
}

\begin{abstract}
Optimal induction of $\mathrm{p} 53$ protein after DNA damage requires RPL26-mediated increases in p53 mRNA translation. We report here the existence of a dsRNA region containing complementary sequences of the $5^{\prime}$ - and $3^{\prime}$-untranslated regions (UTRs) of human p53 mRNA that is critical for its translational regulation by RPL26. Mutating as few as 3 bases in either of the two complementary UTR sequences abrogates the ability of RPL26 to bind to p53 mRNA and stimulate p53 translation, while compensatory mutations restore this binding and regulation. Short, single-strand oligonucleotides that target this $5^{\prime}-3^{\prime}$-UTR base-pairing region blunt the binding of RPL26 to p53 mRNA in cells and reduce p53 induction and p53-mediated cell death after several different types of DNA damage and cellular stress. The ability to reduce stress induction of p53 with oligonucleotides or other small molecules has numerous potential therapeutic uses.
\end{abstract}

[Keywords: p53; translational control; DNA damage; cytoprotection]

Supplemental material is available at http://www.genesdev.org.

Received July 12, 2010; revised version accepted August 12, 2010.

Cellular DNA is constantly damaged by endogenous molecules, such as reactive oxygen species, and exogenous sources, including natural or man-made chemicals and radiation. Effective responses to such damage are critical to reduce disease burden, including cancer development. The high incidence of cancer seen in individuals who inherit mutations in genes involved in DNA damage responses-such as ATM, p53, BRCA1, and BRCA2-underscores the important role that such responses play in tumorigenesis (Kastan and Bartek 2004). In addition, since most current cancer therapeutics target cellular DNA, cellular responses to DNA damage are also critical determinants of both tumor responses to therapy and the side effects of cancer treatments. The p53 gene product is particularly important in this regard, since the gene is mutated in $>50 \%$ of sporadic human tumors, and inheritance of germline $p 53$ mutations leads to a profound susceptibility to cancer development (Malkin et al. 1990; Levine 1997; Olivier et al. 2010). p53 protein transcriptionally regulates a complex network of genes involved in tumor suppression, metabolism, autophagy, and various

${ }^{1}$ Corresponding author.

E-MAIL michael.kastan@stjude.org; FAX (901) 595-3966.

Article published online ahead of print. Article and publication date are online at http://www.genesdev.org/cgi/doi/10.1101/gad.1968910. physiological and pathological processes (Levine and Oren 2009). Levels of p53 protein increase in cells following exposure to DNA damage and other stresses, leading to cellular responses such as cell cycle arrest or programmed cell death (Kastan and Bartek 2004). An ability to modulate stress induction of p53 in tumor cells or normal cells could prove to be useful in various clinical settings.

Increases in p53 protein levels after DNA damage have been largely attributed to increases in the half-life of p53 protein. Proteasome-mediated degradation of p53 protein regulated by the E3-ubiquitin ligase $\mathrm{Mdm} 2$ helps maintain low levels of p53 protein in nonstressed cells (Haupt et al. 1997; Honda et al. 1997; Kubbutat et al. 1997). Cellular exposure to DNA damage results in an inhibition of Mdm2-mediated degradation of p53 protein, contributing to an increase in p53 protein half-life and increased cellular levels of p53 protein (Ashcroft and Vousden 1999; Wade et al. 2010). We reported recently that increased translation of p53 mRNA is also a requisite step for optimal p53 induction following DNA damage (Takagi et al. 2005). In particular, we found that RPL26 protein binds to the 5 ' -untranslated region (UTR) of p53 mRNA after DNA damage, enhances the association of p53 mRNA with heavy polysomes, and increases the translation of p53 mRNA. Furthermore, the Mdm2-p53 feedback loop, which regulates p53 levels after DNA damage (Levine 1997; Prives 
1998; Michael and Oren 2003), also appears to involve Mdm2-RPL26 interactions, which affect p53 translation (Ofir-Rosenfeld et al. 2008). Down-regulation of RPL26 protein levels with siRNA not only reduces the increases in p53 translation seen after DNA damage, it also reduces increases in total p53 protein levels and cell death after DNA damage (Takagi et al. 2005). Thus, blockade of RPL26-mediated translational induction of $\mathrm{p} 53$ is sufficient to reduce p53 induction and p53-mediated cell death.

We report here that translation of human p53 mRNA is regulated by base-pairing interactions between $5^{\prime}$ - and $3^{\prime}$-UTR sequences. Mutations that disrupt the interaction abolish the binding of RPL26 to human p53 mRNA and diminish RPL26-dependent p53 induction. Compensatory mutations that restore this UTR interaction rescue the RPL26 binding as well as translational regulation of p53 by RPL26. Small, single-strand oligonucleotides containing critical sequences from this RNA interaction region inhibit the binding of RPL26 to p53 mRNA and blunt p53 induction after exposure of cells to a variety of DNAdamaging agents. These observations demonstrate a novel mechanism of regulating cellular protein levels and provide a reagent (oligonucleotides) that can be used to modulate stress induction of p53 in cells-a potentially clinically useful intervention. These mechanistic insights also set the stage for identifying small molecules other than oligonucleotides that could modulate p53 induction by targeting this mechanism.

\section{Results}

p53 mRNA contains a dsRNA structure

with base-pairing between the 5'- and 3'-UTRs

RPL26 stimulation of p53 translation requires the $5^{\prime}$-UTR, but not the coding sequence, of p53 mRNA (Takagi et al. 2005; Ofir-Rosenfeld et al. 2008). This 5'-UTR translational dependence was recapitulated by a cell-based, dual-luciferase reporter assay, in which RPL26 selectively enhanced the expression level of a chimera firefly luciferase reporter gene containing a $5^{\prime}$-UTR sequence of human p53 mRNA relative to the expression of the internal control renilla luciferase gene (Fig. 1A). Unexpectedly, adding the 3'-UTR sequence of human p53 mRNA further enhanced RPL26 stimulation of firefly luciferase expression (Fig. 1A). This observation raised the question of why RPL26 stimulation would simultaneously require both UTR sequences, so mathematical modeling of the p53 mRNA structure was performed using an RNAfold program (http://www.tbi. univie.ac.at/RNA) to predict the minimum free energy secondary structure of human p53 mRNA (Hofacker 2004; Gruber et al. 2008). This analysis suggested the presence of a dsRNA structure containing a 21 - to 18 -base $\left(5^{\prime}-3^{\prime}\right)$ complementary region between the two UTRs including 5 '-UTR sequences -54 to -34 (numbering from the start codon) and 3'-UTR sequences +335 to +352 (numbering after the stop codon) (Fig. 1B; Supplemental Fig. S9). Similar 5'-3'-UTR interaction structures were also predicted in p53 mRNAs from several species-including other primates, rodents, Xenopus, and zebrafish-by using the RNAfold program (Supplemental Fig. S1).
To determine if such a $5^{\prime}-3^{\prime}$-UTR dsRNA structure existed in p53 mRNA, human p53 mRNA was probed with single-strand-specific (RNases A and T1) and doublestrand-specific (RNase V1) RNase enzymes. RNase A specifically recognizes ssRNA and cuts at the $3^{\prime}$ side of $\mathrm{C} / \mathrm{U}$ bases, while RNase $\mathrm{T} 1$ cuts at the $3^{\prime}$ side of $\mathrm{G}$ bases in ssRNA. The vast majority of cellular p53 mRNA contains 5'-UTRs with $140-170$ bases (Takagi et al. 2005), so a p53 mRNA containing 145 bases of the $5^{\prime}$-UTR and either containing or lacking a full-length $3^{\prime}$-UTR was transcribed in vitro, end-labeled at the $5^{\prime}$ end with ${ }^{32} \mathrm{P}$, and digested with RNase A or RNase T1. RNase A treatment of an endlabeled p53 mRNA lacking a 3'-UTR resulted in a prominent band migrating at a molecular weight consistent with cutting next to the uridine at position -36 in the $5^{\prime}$-UTR $[\mathrm{U}(-36)]$ (Fig. 1C [lane 6], D [lanes 1,3]; Supplemental Fig. S2). In contrast, RNase A failed to cut at this $5^{\prime}$-UTR site (Fig. 1D, lane 5) if the RNA lacking the 3'-UTR was mutated at U(-36) (UGG to AAA, -36 to -34 ) (Fig. 1B, $5^{\prime}$-UTR mutation $\left./ 5 \mathrm{M}\right)$, thus confirming this as the site of RNase A cutting. Addition of a full-length 3'-UTR sequence to the p53 mRNA blocked RNase A cutting at $\mathrm{U}(-36)$ (Fig. 1C, lane 7), consistent with the appearance of a dsRNA structure at this $5^{\prime}$-UTR site when the $3^{\prime}$-UTR is included in the p53 mRNA. Interestingly, a new prominent band appeared when the full-length, wild-type p53 mRNA was digested with the $\mathrm{C} / \mathrm{U}$-directed, single-strand-specific RNase A (Fig. 1C, lane 7, band noted by arrowhead). This new band runs at a size consistent with cutting at the $\mathrm{C} / \mathrm{U}(-52 /-49)$ sites in the putative double-strand region, the unpaired bases in this 21-base 5'-UTR region (Fig. 1B). Mutating as few as 3 bases in the predicted interacting region of the $3^{\prime}$-UTR, which should disrupt the basepairing of the two UTRs at this site, was sufficient to partially restore RNase A cutting at $\mathrm{U}(-36)$ (Fig. 1C, lane 8). RNase A cutting at $U(-36)$ of a p53 mRNA lacking a 3'-UTR could even be abrogated by simple addition of a DNA oligonucleotide complementary to the predicted 5 '-UTR-interacting region (Fig. 1D, lane 2), as would be expected from the creation of a double-strand structure at this site. Importantly, addition of a control oligonucleotide that would not pair with this $5^{\prime}$-UTR region failed to abrogate RNase A cutting at this site in the p53 mRNA lacking the 3'-UTR (Fig. 1D, lane 4).

Digestion of the various p53 mRNA species with the other single-strand-specific RNase, the G-directed RNase T1 enzyme, gave similar results, cutting both a p53 mRNA lacking the $3^{\prime}$-UTR and a full-length p53 mRNA mutated at the $3^{\prime}$-UTR-interacting site at $\mathrm{G}(-34 /-35)$ (Fig. 1C, lanes 10,12, respectively). Consistent with a dsRNA region, RNase T1 failed to cut full-length, wild-type p53 mRNA (Fig. 1C, lane 11), and, consistent with cutting at this specific site, RNase T1 failed to cut p53 mRNA if the $\mathrm{G}(-34 /-35)$ putative cutting site was mutated (Fig. 1C, lane 13). Digestion with the double-strand-specific RNase V1 followed by primer extension gave complementary results that similarly demonstrated the presence of a dsRNA structure in the putative base-pairing region (Fig. 1E; Supplemental Fig. S2). RNase V1 failed to cut p53 mRNA lacking a 3'-UTR (Fig. 1E, lanes 7,9, uncut major 
A
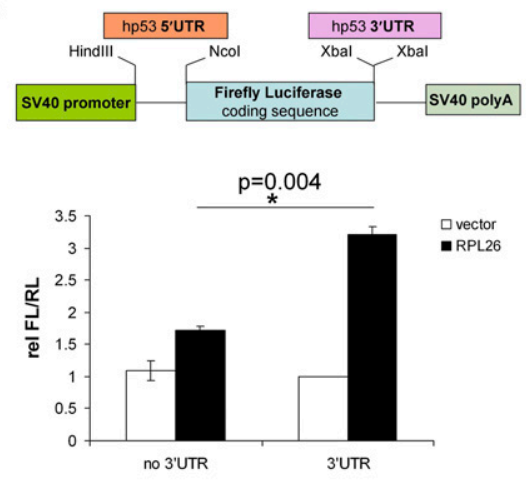

B

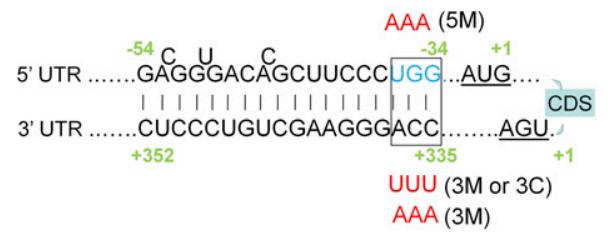

C

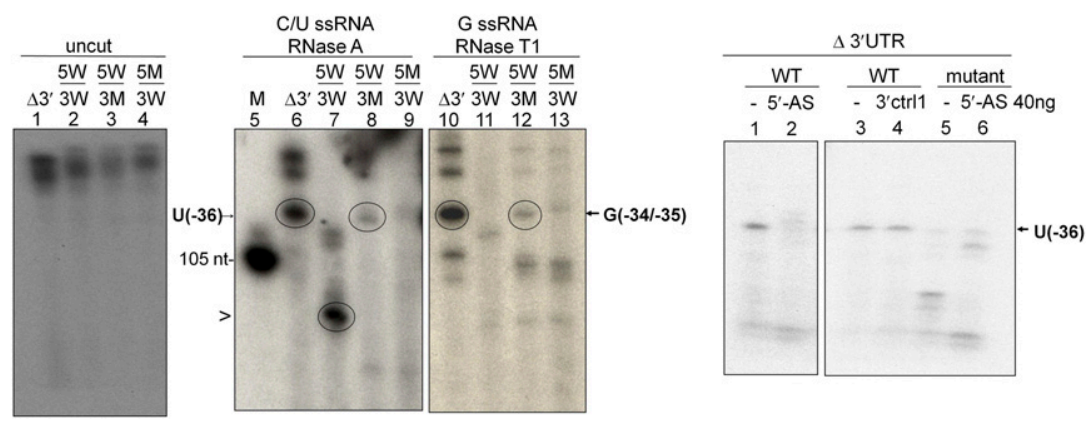

E

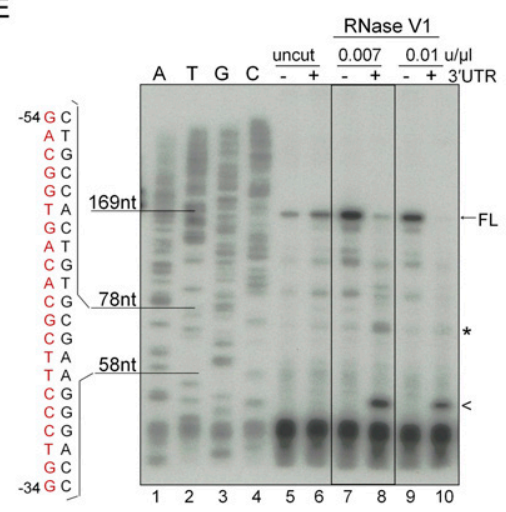

Figure 1. A dsRNA region involving base-pairing of 5 '- and 3 '-UTR sequences exists in human p53 mRNA. (A) The $3^{\prime}$-UTR sequence is required for optimal RPL26 stimulation of a reporter gene containing the p53 UTRs. MCF-7 cells were transiently transfected with empty vector (vector) or Flag-RPL26 (RPL26) together with firefly luciferase constructs (FL), as illustrated in the schematic diagram, plus a control renilla luciferase expression construct (RL). The relative FL/RL ratio was calculated by normalizing the FL/RL ratio of each sample to the ratio in cells transfected with empty vector (instead of RPL26), renilla luciferase, and the firefly luciferase construct containing a 145-base 5 '-UTR and full-length 3 '-UTR of human p53. Data shown are average $\pm \mathrm{SD}$ for three independent experiments. $\left({ }^{\star}\right) P=$ 0.004 (Student's $t$-test). (B) Minimum free energy computational modeling predicts a dsRNA region containing complementary sequences of the 5 '- and 3 '-UTRs of human p53 mRNA. The schematic diagram shows the sequence and position of these bases in full-length human p53 mRNA, with the start and stop codons underlined, the coding sequence (CDS) noted, and the mutations made in the various constructs used in these studies shown. The detailed information about the mutations introduced into this base pair region is summarized in Supplemental Table 1. (C) The p53 5'-UTR sequence loses its single-strand nature in the presence of the p53 3'-UTR. Wild-type or mutated p53 mRNA containing a 145-base $5^{\prime}$-UTR and coding sequence without $\left(\Delta 3^{\prime}\right)$ or with $(5 \mathrm{~W} / 3 \mathrm{~W})$ a full-length $3^{\prime}$-UTR was

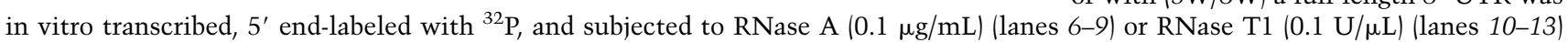
digestion. The digestion products were separated on a 15\% UREA-TBE PAGE gel. The arrow indicates cutting at the U(-36) position in the 5'-UTR (109-base product). The arrowhead indicates cutting at the U(-49)/C(-51) position (93/96-base product). (M) A 105-base RNA marker. (Lane 7) 5W/3W; wild-type UTRs. (Lane 8) 5W/3M; wild-type 5'-UTR and 3'-UTR with mutation. (Lane 9) 5M/3W; $5^{\prime}$-UTR with mutation and wild-type $3^{\prime}$-UTR. (D) A 21-base DNA oligonucleotide complementary to the $5^{\prime}$-UTR $\left(5^{\prime}\right.$-AS) is sufficient to restore the double-strand structure at U(-36). (Left panel) p53 mRNA lacking the $3^{\prime}$-UTR and containing a wild-type or mutated 75-base $5^{\prime}$-UTR and a p53 coding sequence was in vitro transcribed, $5^{\prime}$ end-labeled with ${ }^{32} \mathrm{P}$, and subjected to RNase A digestion $(0.1 \mu \mathrm{g} /$ $\mathrm{mL})$. The arrow indicates cutting at the $\mathrm{U}(-36)$ position in the $5^{\prime}$-UTR. (WT) Wild-type $5^{\prime}-\mathrm{UTR}_{\text {; }}$ (mutant) $5^{\prime}$-UTR with mutation. $3^{\prime}$ ctrll is a control oligonucleotide complementary to a $5^{\prime}$-UTR sequence outside of the predicted interactive region $(-74$ to -53$)$. The digestion products were separated on a $15 \%$ UREA-TBE PAGE gel. $(E)$ The p53 3 '-UTR sequence promotes a dsRNA structure in the p53 5'-UTR. Wild-type p53 mRNA containing a 145-base 5'-UTR and coding sequence without (-) or with (+) a full-length 3'-UTR were in vitro transcribed and subjected to RNase $\mathrm{V} 1$ digestion $(0.1 \mathrm{U} / \mu \mathrm{L})$ followed by reverse transcription (primer extension). RNase $\mathrm{V} 1 \mathrm{was}$ diluted 10-fold $(0.01 \mathrm{U} / \mu \mathrm{L})$ or 14-fold $(0.007 \mathrm{U} / \mu \mathrm{L})$. Sequencing (lanes 1-4) and cleavage/primer extension reactions (lanes 5-10) were performed with an oligonucleotide primer complementary to the p53 coding sequence close to the 3 ' end of the ATG start codon $(+2$ to +24 ) (see Supplemental Table 2 for sequence). Sequencing reaction products and primer extension products were separated on a $15 \%$ Urea-TBE PAGE gel. The arrow indicates the full-length extension product (FL). The asterisk indicates a cleavage product created by cutting within the predicted dsRNA region (seen only with limited digestion), and the arrowhead indicates a cleavage product generated by cutting out the entire predicted dsRNA structure, both seen only in the presence of the $3^{\prime}$-UTR. The open bracket shows the location and the sequence of the $5^{\prime}$-UTR strand of the putative base-pairing region.

primer extension product noted by FL), but it digested virtually the whole predicted double-strand region when a $3^{\prime}$-UTR was present, resulting in a new, much shorter primer extension product that stopped before this puta- tive 5 '-UTR sequence (Fig. 1E, lanes 8,10, new band noted by arrowhead). Interestingly, limited RNase V1 digestion ( $14 \times$ dilution, $0.007 \mathrm{U} / \mu \mathrm{L}$ ) also revealed a preferred site of cutting within the putative base-pairing region at $\mathrm{G}(-50 /$ 
-51) only in the RNA containing a 3'-UTR (Fig. 1E, lane 8, band noted by asterisk), consistent with a dsRNA structure at this site. Thus, all three RNases demonstrate the presence of a dsRNA structure involving base-pairing of the predicted $5^{\prime}$ - and $3^{\prime}$-UTR sequences.

\section{The 5'-UTR and 3'-UTR base-pairing region is required} for RPL26 binding and modulation of p53 translation

Since both UTRs affect the translational regulation of p53 by RPL26, and since we identified a region of base-pairing between the UTRs, we asked whether these UTR interactions affect RPL26-mediated regulation of p53 translation. Mutating the last 3 bases of the interacting region (Fig. 1B) in either the $5^{\prime}$ UTR $\left(5 \mathrm{M} / 3 \mathrm{~W}\right.$, UGG to AAA), the $3^{\prime}$ UTR (5W/3M, CCA to UUU), or both $\left(5 \mathrm{M} / 3 \mathrm{M}\right.$; $5^{\prime}$-UTR, UGG to AAA; 3'-UTR, CCA to AAA) abolished the stimulation of the reporter by RPL26 (Fig. 2A). The same mutations introduced into an upstream site in the $5^{\prime}$-UTR outside of the interacting region ( -64 to $-62,5^{\prime}$-UTR, UGC to AAA) did not affect the ability of RPL26 to stimulate luciferase activity (Fig. 2A, ctrl mut). A compensatory double mutation that should restore the base-pairing of the last 3 bases (5M/3C; 5'-UTR, UGG to AAA; 3'-UTR, CCA to UUU)

A

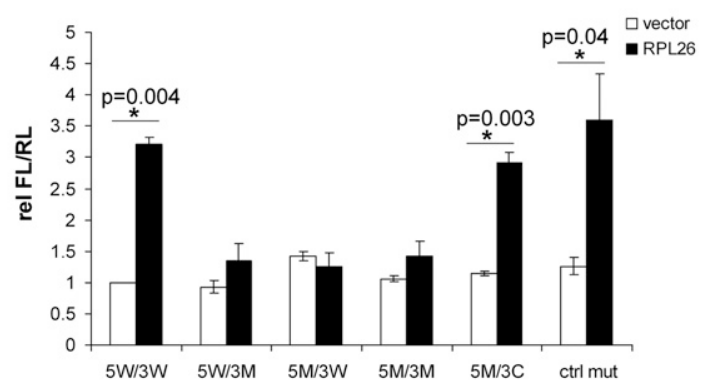

B

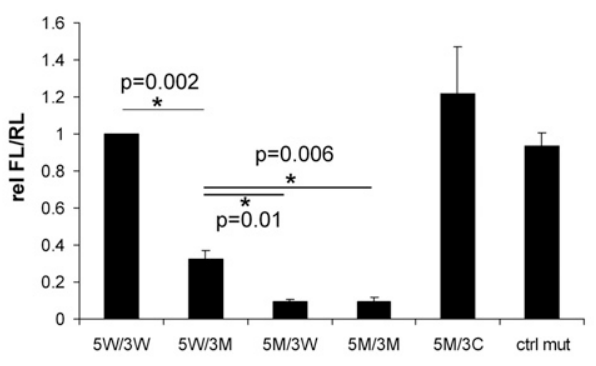

C

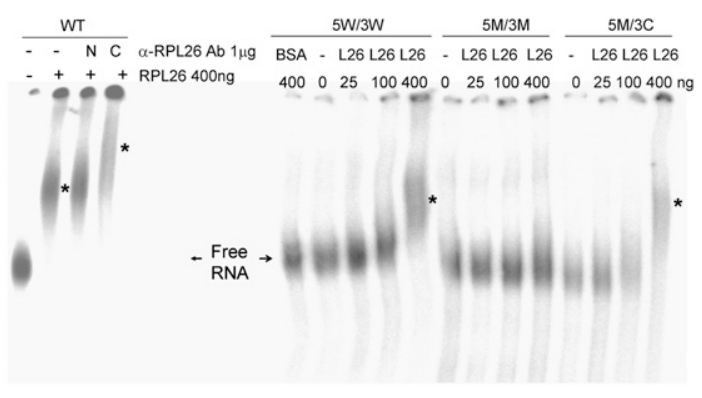

restored the ability of the reporter to respond to RPL26 regulation. None of the mutations affected expression levels of the introduced RNAs (Supplemental Fig. S3) or basal reporter activity. These results suggest that basepairing interactions of the last 3 base pairs (bp) of the UTRinteracting region are particularly important in regulating the translation of p53 mRNA by RPL26.

RPL26 binds to p53 mRNA in cells after DNA damage and stimulates its translation (Takagi et al. 2005; OfirRosenfeld et al. 2008). It is notable that RPL26 binds to p53 mRNA in the nucleus after damage (Supplemental Fig. S4), suggesting that these effects may represent an extraribosomal function of RPL26. We examined the role of this UTRinteracting region in modulating the ability of RPL26 to bind to p53 mRNA. Wild-type or mutant p53 mRNAs with $5^{\prime}$ caps and $3^{\prime}$ poly(A) tails were transcribed in vitro and transfected into p53-null H1299 cells, and the ability of endogenous RPL26 protein to bind to p53 mRNA was assessed. Although RPL26 bound to p53 mRNA with wildtype UTR sequences, it failed to bind p53 mRNA with mutations that disrupt the interactions of the last $3 \mathrm{bp}$ (Fig. $2 \mathrm{~B})$, whether the mutations were in the $3^{\prime}$-UTR $(5 \mathrm{~W} / 3 \mathrm{M})$, the $5^{\prime}$-UTR $(5 \mathrm{M} / 3 \mathrm{~W})$, or both $(5 \mathrm{M} / 3 \mathrm{M})$. Consistent with the reporter assay (Fig. 2A), compensatory mutations (5M/ $3 \mathrm{C})$ rescued the binding of RPL26 to p53 mRNA, which confirms the dependence of RPL26 on the double-strand structure at the position of these $3 \mathrm{bp}$ for optimal binding to p53 mRNA. The slightly greater binding of RPL26 to the $5 \mathrm{~W} / 3 \mathrm{M}$ mutant $\left(3^{\prime}\right.$ mutation only) than to the $5 \mathrm{M} / 3 \mathrm{~W}$ or

Figure 2. The last $3 \mathrm{bp}$ in the putative $5^{\prime}, 3^{\prime}$-UTR dsRNA structure are required for optimal RPL26 stimulation of p53 translation. (A) Mutations inside the UTR-interacting region modulate p53 reporter gene induction by RPL26. Mutations (as indicated in Fig. 1B; Supplemental Table 1) were introduced into the $5^{\prime}$-UTR $(5 \mathrm{M} / 3 \mathrm{~W}), 3^{\prime}$-UTR $(5 \mathrm{~W} / 3 \mathrm{M})$, or both $(5 \mathrm{M} / 3 \mathrm{M})$, including a compensatory mutation $(5 \mathrm{M} / 3 \mathrm{C})$ that restores complementarity or an identical $5^{\prime}$-UTR control mutation (ctrl mut) upstream (-64 to -62$)$ of the UTR-interacting region. The dualluciferase reporter assay was performed as in Figure 1A. Data shown are average \pm SD for three independent experiments. $P$-values were calculated using Student's $t$-test. $(B)$ Mutations inside the UTR-interacting region affect binding of RPL26 protein to human p53 mRNA in cells. In vitro transcribed wild-type or mutated p53 mRNAs with $5^{\prime}$ cap and $3^{\prime}$ polyadenylation modifications were transfected into H1299 cells. Endogenous RPL26 was immunoprecipitated $16 \mathrm{~h}$ post-transfection and the bound p53 mRNA was measured by real-time RT-PCR. The bar graphs show the ratio of the bound p53 mRNA level compared with that seen in cells with wild-type p53 mRNA. The error bars represent average \pm SD for three experiments. $P$-values were calculated using Student's $t$-test. $(C)$ Mutations in the UTR-interacting region affect the binding of RPL26 protein to human p53 mRNA in vitro. RNA-EMSA was performed to detect the binding of recombinant RPL26 protein (amino acids 45-145) to in vitro transcribed, $5^{\prime}$ end ${ }^{32} \mathrm{P}$-labeled wild-type or mutated p53 mRNA with a 145-base 5'-UTR and full-length 3'-UTR. In the left panel, an antibody raised against the $\mathrm{N}$ terminus (N) or C terminus (C) of RPL26 protein was used for supershift. Asterisks indicate the positions of mobility retarded protein-RNA complexes. 
$5 \mathrm{M} / 3 \mathrm{M}$ mutants (Fig. $2 \mathrm{~B}$ ) is consistent with the low-level stimulation of translation by RPL26 in an mRNA containing just the $5^{\prime}$-UTR (Fig. 1A), and suggests a low-level binding and stimulation associated with the $5^{\prime}$-UTR sequence alone. These UTR mutations did not affect the levels of p53 mRNA in cells, the basal p53 mRNA translation, or the level of RPL26 protein during the time frame of the study (Supplemental Fig. S5). Thus, the effects of RPL26 on reporter expression and p53 mRNA binding cannot be attributed to alterations in RNA transcription or stability. Finally, purified, recombinant RPL26 protein is able to directly bind to p53 mRNA in vitro (Fig. 2C, left panel), and this binding is abrogated by deletion of the $3^{\prime}$-UTR (Supplemental Fig. S6) or by mutation of the $5^{\prime}-3^{\prime}$-UTR-interacting region (Fig. 2C, 5M/3M) and is restored by compensatory mutations that restore complementarity of this region (Fig. 2C, 5M/3C).

\section{Disruption of the UTR-interacting region affects damage induction of p53 in cells}

In order to explore the role of the $5^{\prime}$ - and $3^{\prime}$-UTR basepairing sequences in regulating p53 translation and p53 induction after DNA damage in cells, we attempted to disrupt the $55^{\prime}-3$ '-UTR interaction by transfecting 21 -base ssDNA oligonucleotides complementary to either the 5 ' - or 3'-UTR-interacting sequences into MCF-7 cells and examining potential effects of these oligonucleotides on p53 induction after DNA damage. Introduction of oligonucleotides complementary to either the $3^{\prime}$-UTR sequence (Fig. 3A, left panel, 5'oligo) or 5'-UTR sequence (Fig. 3A, right panel, 5'AS), but not control oligonucleotides, blunted induction of endogenous p53 following ionizing irradiation (IR). The inhibitory effects of complementary oligonucleotides that can bind either the $5^{\prime}$ - or $3^{\prime}$-UTR sequences are consistent with a model in which this UTR-interacting region is important for p53 regulation. In order to determine the optimal or minimal oligonucleotide sequence length required for this inhibition, serial deletions were made by progressively shortening the interfering oligonucleotides by 3 bases on either end of the $5^{\prime}$ oligonucleotide sequence (complementary to the $3^{\prime}$ interactive sequence). While oligonucleotides containing the last bases in the $5^{\prime}$-UTR interactive sequences (L18, L15, L12, and L9) retained full inhibitory activity, removal of the last 3 bases in each case (F18, F15, F12, and F9) abrogated inhibitory activity (Fig. 3B,C). It is noted that F18 and L18, for example, have significant sequence overlap, sharing 15 out of 18 bases in common, but exhibit markedly different activities in these assays. As long as the final 3 bases in the sequence were preserved, oligonucleotides as short as 8-9 bases could blunt p53 induction after IR (Fig. 3C). Importantly, addition of the oligonucleotides caused no changes in the basal levels of p53 mRNA in cells with or without IR, and no changes of the half-life of p53 mRNA (Supplemental Fig. S7A). Fifteen-base oligonucleotides are short enough to have the potential to enter cells without transfection, and simple incubation of the L15 oligonucleotide with cultured MCF-7 cells was able to reduce p53 induction after IR (Fig. 3D). Thus, L15 has the potential to be used as a small molecule inhibitor of p53 induction.

The importance of the last 3 bases in these oligonucleotide sequences in blocking p53 induction in cells was reminiscent of the importance of these same 3 bases in translational regulation of p53 reporters carrying full-length p53 UTRs in the dual-luciferase reporter assay (Fig. 2A) and in determining the binding of RPL26 protein to p53 mRNA in cells (Fig. 2B) or in vitro (Fig. 2C). To further explore the importance of these last 3 bases in the interacting sequence, oligonucleotides were generated in which various bases in L15 were mutated and tested for their ability to blunt p53 induction after DNA damage in cells. While L15 oligonucleotides containing mutations of either the first 3 bases $(\mathrm{m} 1)$ or the middle 6 bases $(\mathrm{m} 2)$ of the critical sequence partially lost inhibitory activity, mutation of the last 3 bases (m3) abrogated all inhibitory activity (Fig. 3E).

Optimal IR-induced increases in p53 protein levels are dependent on increases in p53 protein translation and require the binding of RPL 26 to the $5^{\prime}$-UTR of p53 mRNA (Takagi et al. 2005; Ofir-Rosenfeld et al. 2008). Similar to its blocking effects on p53 induction following IR, addition of L15 to cells blunted p53 induction caused directly by overexpression of RPL26 (Fig. 3F). Along with the observation that disruption of the UTR-interacting sequence by mutation could disrupt the binding of RPL26 to p53 mRNA (Fig. 2B,C), this observation suggested that the ability of the oligonucleotides to blunt p53 induction after IR could result from blockade of the binding of RPL26 to p53 mRNA. As noted previously (Takagi et al. 2005), RPL26 binding to endogenous p53 mRNA is detectable after IR by immunoprecipitation of RPL26 protein followed by RT-PCR (IP-RT-PCR) to quantitate the amount of p53 mRNA bound to RPL26 (Fig. 3G; Supplemental Fig. S7B). Transfection of cells with L15, but not the control F15 oligonucleotide, blocked the enhanced binding of RPL26 to p53 mRNA in IR-treated cells (Fig. 3G; Supplemental Fig. S7B, right panel). Addition of a 15-base oligonucleotide that would mimic the $3^{\prime}$-UTR-interacting sequence and bind to the 5'-UTR (L15-AS) also blocked RPL26 binding to p53 mRNA.

Since DNA oligonucleotides were used for these experiments, it was possible that the DNA-RNA hybrids generated could engage RNase $\mathrm{H}$ activity and that the oligonucleotide effects we observed were attributable to differential degradation of p53 mRNA. This seemed unlikely, since the p53 inhibitory activities (or lack thereof) of the different oligonucleotides did not correlate with their complementarity to the p53 mRNA sequence. Nevertheless, to ensure that the oligonucleotides were blunting p53 induction by blocking the binding of RPL26 protein to p53 mRNA and not by leading to changes in the levels of p53 mRNA, we used quantitative, real-time PCR to assess levels of p53 mRNA following exposure to the various oligonucleotides. Despite measurable differences in impacting RPL26 binding and p53 induction after IR, there was no measurable impact on the levels of p53 mRNA with the various oligonucleotides (Supplemental Fig. S7A,B). To further rule out the potential of RNase $H$ 
A

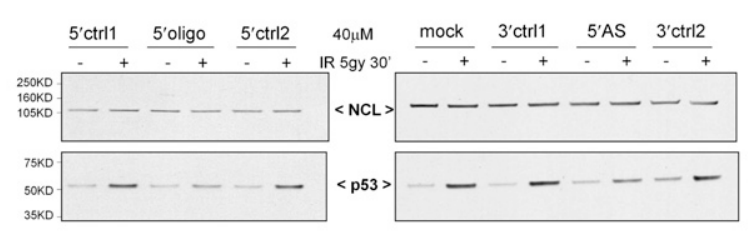

B
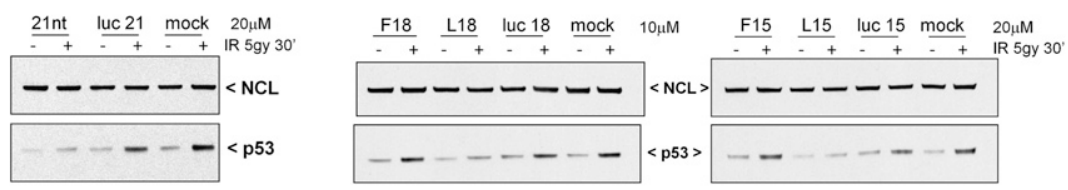

C

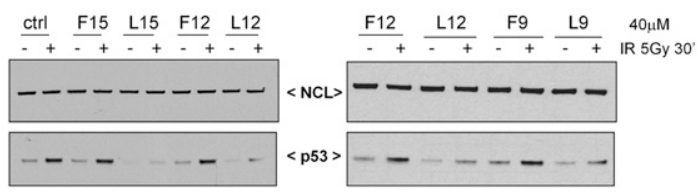

D

E

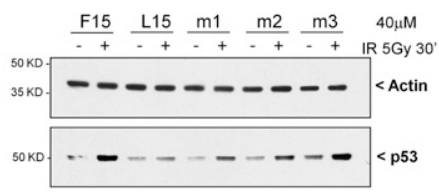

G

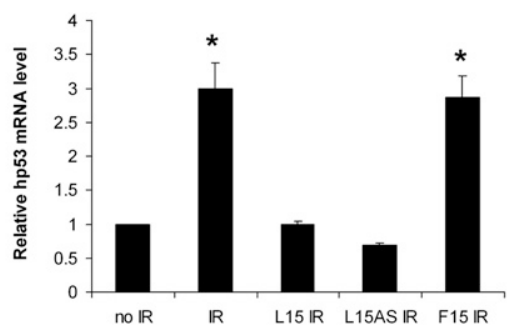

F

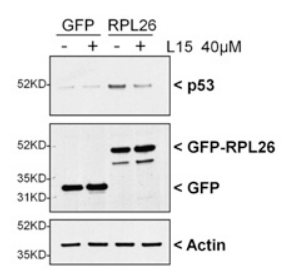

$\mathrm{H}$

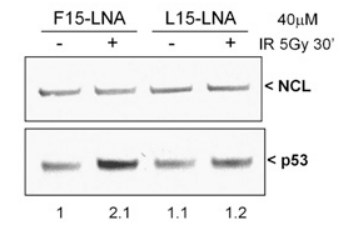

Figure 3. DNA oligonucleotides targeting the UTR-interacting region inhibit p53 induction and RPL26 binding. (A) DNA oligonucleotides complementary to either the 5'- or 3'-UTR-interacting regions block p53 induction. MCF-7 cells were transfected with the indicated amounts of 21-base oligonucleotides using Lipofectamine RNAi MAX or Lipofectamine 2000 (Invitrogen). Oligonucleotides were complementary to the interacting sequences of the $3^{\prime}$-UTR (5'oligo), the $5^{\prime}$-UTR $\left(5^{\prime}\right.$-AS), or UTR sequences from nearby surrounding regions $\left(5^{\prime}\right.$ or $3^{\prime}$ ctrll or ctrl2). Twentyfour hours post-transfection, MCF-7 cells were irradiated ( 0 or 5 Gy IR), harvested 30 min later, and immunoblotted for p53 and NCL proteins. $(B)$ A 15-base fragment of the 21-base 5 'oligo is sufficient to block p53 induction by IR. p53 induction $30 \mathrm{~min}$ after 5 Gy IR was assessed in MCF-7 cells transfected with various oligonucleotides as described in $A$. (5'oligo) 21-nt $5^{\prime}$-UTRinteracting sequence; (F18) the first 18 bases of the 21-nt 5 'oligo; (L18) the last 18 bases of the 21 -nt 5 'oligo; (F15) the first 15 bases of L18; (L15) the last 15 bases of L18. Luc21, luc18, and luc15 were oligonucleotides of the luciferase coding sequence with indicated length. (C) Small DNA oligonucleotides can block IR induction of p53. MCF-7 cells were transfected with shorter oligonucleotides generated by serial deletion of L15 from the 5' end (L12, L9, L8, and L7) for $24 \mathrm{~h}$. p53 induction was assessed in transfected cells $30 \mathrm{~min}$ after 5 Gy IR. Oligonucleotides (F12 and F9) generated by deletion from the $3^{\prime}$ end of F15 were used as controls. (D) L15 can enter cells and block p53 induction in the absence of transfection. Oligonucleotides (40 $\mu \mathrm{M})$ were incubated with MCF-7 cells for $24 \mathrm{~h}$ prior to 0 or 5 Gy IR and p53 induction was assessed after $30 \mathrm{~min}$. (E) Point muta-

tions in L15 abolish its blocking effect on p53 induction. p53 induction was assessed $24 \mathrm{~h}$ after addition of F15, L15, or mutated L15 to MCF-7 cultures and $30 \mathrm{~min}$ after 0 or 5 Gy IR. The sequences of L15, $\mathrm{m} 1, \mathrm{~m} 2$, and m3 are GACACGCTTCCCTGG, TTTACGCTTCCCTGG, GACACAACCAACTGG, and GACACGCTTCCCAAA, respectively. $(F)$ L15 blocks RPL26 induction of p53. GFP and GFP-RPL26 were transfected into MCF-7 cells and L15 was added to the medium where indicated $6 \mathrm{~h}$ later. p53 levels were assessed $24 \mathrm{~h}$ post-transfection. $(G)$ L15 blocks the binding of RPL26 to p53 mRNA in irradiated cells. Thirty minutes after 10 Gy IR, endogenous RPL26 was immunoprecipitated from MCF-7 cells that had been transfected with $40 \mu \mathrm{M}$ of the indicated oligonucleotide $24 \mathrm{~h}$ earlier. p53 mRNA bound to RPL26 was quantified by real-time RT-PCR. The bar graphs show the ratio of the p53 mRNA level to that in untreated cells. The error bars represent average \pm SD for three experiments. $\left({ }^{\star}\right) P=0.01$ (Student's $t$-test). $(H)$ The LNA-modified L15 (L15-LNA) DNA oligonucleotide inhibits p53 induction. p53 induction 30 min after 5 Gy IR was assessed in MCF-7 cells transfected with L15-LNA. LNA-modified F15 (F15-LNA) is used as a control. Fold increase of p53 protein level is shown below the blot. The band intensity of p53 in each lane was quantified using Image J and normalized to the band intensity of NCL and then compared with the F15-LNA transfected, no-IR-treated lane (first lane).

contributions, "locked" (LNA [locked nucleic acid]) oligonucleotides were synthesized that would not be able to engage RNase $\mathrm{H}$ activity in the cell when bound to p53 mRNA. Introduction of these "locked" oligonucleotides gave results identical to those seen with unmodified DNA oligonucleotides in that the F15 sequence had no impact on p53 induction after IR, while L15 locked oligonucleo- tides blunted p53 induction (Fig. 3H). Finally, L15 had no impact on p53 induction following Nutlin treatment, which increases cellular p53 protein levels via increased p53 protein half-life by blocking Mdm2-mediated degradation of p53 protein (Supplemental Fig. S7C). If L15 were degrading p53 mRNA, p53 induction also should have been compromised in the $18 \mathrm{~h}$ of the nutlin exposure. 
These data, together with the studies described above, demonstrate that disruption of the interactions of the last $3 \mathrm{bp}$ in the $5^{\prime}-3^{\prime}$-UTR-interacting region, whether by introduction of mutations in the mRNA (Fig. 2) or introduction of interfering oligonucleotides (Fig. 3), abolishes the binding of RPL26 to p53 mRNA and blunts the translational induction of p53 by RPL26.

\section{Reagents to modulate stress induction of p53 in cells}

p53 protein is induced by many different types of DNA damage and other stresses (Giaccia and Kastan 1998). Previously, we demonstrated that down-regulation of RPL26 protein with an siRNA blocks p53 induction after either IR or UV irradiation (Takagi et al. 2005). Thus, we asked whether these inhibitory oligonucleotides would block p53 induction following a variety of different stresses. Similar to their effects on IR-treated cells, these oligonucleotides reduced p53 induction after exposure to UV irradiation, alkylating agents (methylmethanesulfonate [MMS]), anti-metabolites (5-fluorouracil [5-FU]), a topoisomerase II inhibitor (etoposide), or a hypoxia mimic (desferoxamine [DFO]) (Fig. 4A). With all of the damaging agents, a quantitative reduction, rather than a complete inhibition, of p53 induction was seen with the oligonucleotide treatments (Fig. 4A; Supplemental Fig. S8).

Since induction of p53 protein can lead to cell cycle arrest or cell death, the abilities of these oligonucleotides to block cell death following stress induction of p53 was also examined. Treatment of p53-competent HCT116 cells with 5-FU induces a p53-dependent apoptotic cell death that can be blocked by down-regulation of RPL26 (Takagi et al. 2005). Simple incubation of parental HCT116 cells with the L15 oligonucleotide attenuated both p53 induction (Fig. 4A) and cell death (Fig. 4B) induced by treatment with 5-FU. L15 had no measurable effect in p53-null HCT116 cells. Similarly, introduction of L15 into HCT116 cells led to a marked p53-dependent growth advantage in cells exposed to the DNA-damaging agent etoposide (Fig. 4C).

\section{Discussion}

It is well established that the binding of the E3-ubiquitin ligase MDM2 to p53 protein regulates the half-life of p53 protein and is a major modulator of both basal and damage-induced p53 protein levels (Ashcroft and Vousden 1999; Michael and Oren 2003). We also reported that increases in p53 mRNA translation are a requisite component of optimal p53 induction following DNA damage and are dependent on the ability of RPL26 protein to bind to the 5'-UTR of p53 mRNA (Takagi et al. 2005; OfirRosenfeld et al. 2008). The data presented here provide significant new mechanistic insights into how p53 translation and p53 induction are regulated by RPL26 and suggest a novel model of mammalian protein translational regulation.

Although we previously reported independent binding of RPL26 protein to the 5'-UTR of p53 mRNA (Takagi et al. 2005), here we provide data demonstrating that RPL26 binding and p53 translational stimulation are further enhanced by the additional presence of the 3'-UTR of p53 mRNA. Having identified a region of complementarity and interaction between the $5^{\prime}$ - and $3^{\prime}$-UTRs of p53 mRNA, we found that the ability of RPL2 6 to bind to p53 mRNA and stimulate its translation are optimal in the presence of this 5'-3'-UTR dsRNA structure. Amazingly, disruption of as few as 3 nucleotides (nt) in the predicted dsRNA structure was sufficient to abrogate RPL26 binding and translational stimulation. Restoration of binding and translational stimulation by compensatory mutations that restore complementarity of these 3 bases demonstrated that the basepairing structure at this site, rather than the primary RNA sequence, plays the dominant role in RPL26 regulation of p53 translation and induction. After DNA damage, the increased translation of p53 mRNA is dependent on the binding of RPL26 to p53 mRNA and the subsequent enhanced association of p53 mRNA with heavy polysomes (Takagi et al. 2005). The mechanism by which RPL26 binding to p53 mRNA is stimulated by exposure of cells to DNA damage remains to be elucidated, but it could involve modulation of Mdm2 binding to RPL26 protein following DNA damage (Ofir-Rosenfeld et al. 2008). The increased binding of RPL26 to p53 mRNA after DNA damage is detectable in the nucleus, suggesting that this mechanism reflects a nonribosomal function of RPL26 protein.

Regulation of protein translation by UTR sequences is not a new concept. UTRs have been implicated in the regulation of protein translation through recruiting protein regulators (Standart and Jackson 1994) or small noncoding RNAs (Vasudevan et al. 2007; Grivna et al. 2006a,b), or by forming secondary structures that affect interactions with translational machinery (Gray and Hentze 1994; Sonenberg and Hinnebusch 2009). Both 5'- and 3'-UTR sequences have been demonstrated to have important roles in controlling translation of eukaryotic mRNAs (Kuersten and Goodwin 2003; Pickering and Willis 2005), including p53 (Mosner et al. 1995; Fu and Benchimol 1997; MazanMamczarz et al. 2003; Schumacher et al. 2005). Among the more typical scenarios would be control of translation mechanisms by $5^{\prime}$-UTR sequences and control of mRNA stability by 3'-UTR sequences (Melefors and Hentze 1993; Sachs 1993). Interactions between $5^{\prime}$ and $3^{\prime}$ mRNA ends in translational control have also been described, including a recent report of two distinctive closed-loop mRNP structures stabilized by eIF4E, eIF4G, and eIF3 initiation factors, which circularize a capped mammalian mRNA by bridging the 5' CAP structure with proteins bound at the 3' poly(A) tail (Sonenberg and Hinnebusch 2007, 2009; Amrani et al. 2008). In this case, the circularization of the mRNA facilitates cap-dependent translation. However, this $5^{\prime}-3^{\prime}$ interaction occurs between generic structures (5' CAP and $3^{\prime}$ poly[A] tail) and is not an interaction between complementary sequences. Gene-specific translational control by interactions between $5^{\prime}$ - and $3^{\prime}$-UTR sequences have been described in bacteria (Franch et al. 1997) and RNA viruses (Edgil and Harris 2006), but rarely in eukaryotic RNAs. An unusual example is the Barley yellow dwarf luteovirus (BYDV) mRNA, which forms 
A
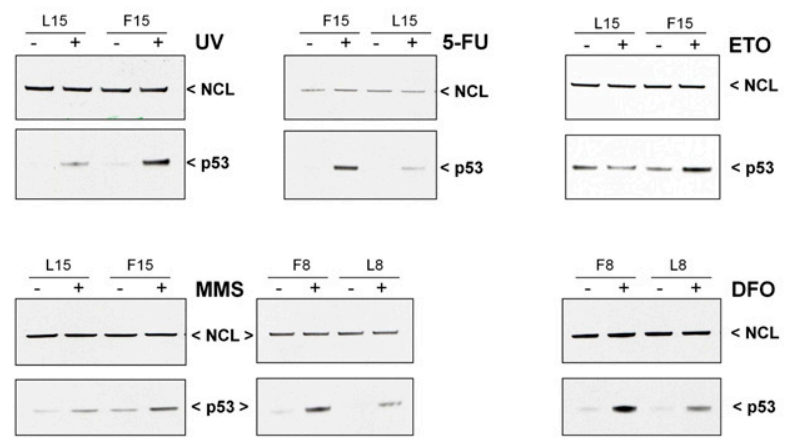

B

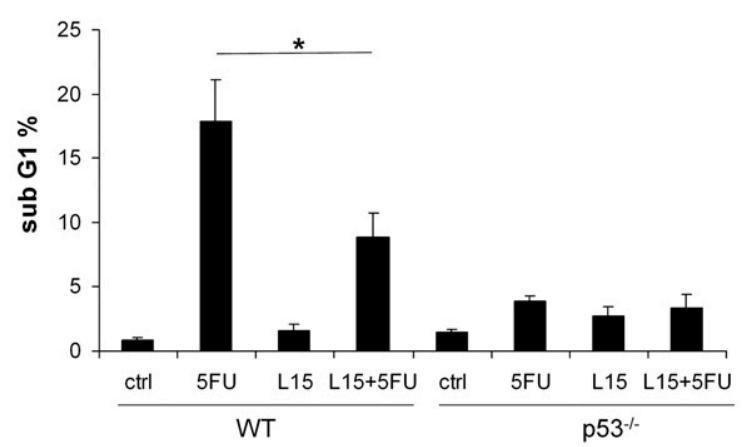

C
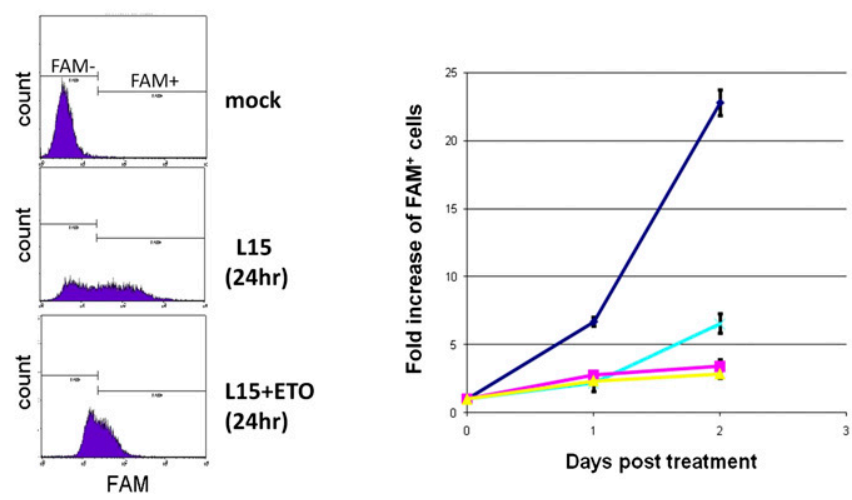

Figure 4. Oligonucleotides targeting the UTR-interacting region are small molecules that can modulate stress induction of p53 and resultant cellular effects in cells. (A, top left) 5'-UTR DNA oligonucleotides block p53 induction following many types of stress. MCF-7 cells were transfected with $40 \mu \mathrm{M} \mathrm{L15} 20 \mathrm{~h}$ before exposure to $5 \mathrm{~J} / \mathrm{m}^{2} \mathrm{UV}$, and p53 induction was assessed $3 \mathrm{~h}$ later. MCF-7 or HCT116 cells were transfected with L15 or L8 for $4 \mathrm{~h}$ before administration of $100 \mu \mathrm{M}$ 5-FU (HCT116WT), $170 \mu \mathrm{M}$ etoposide (ETO) (HCT116WT), $250 \mu \mathrm{M}$ DFO (MCF-7), or $50 \mathrm{ng} / \mathrm{mL}$ methylmethanesulfonate (MMS) (MCF-7) for an additional 20 h, 48 h, 20 h, or $4 \mathrm{~h}$ of incubation, respectively, and p53 induction was assessed by immunoblot. The control oligonucleotide shown is F15 or F8. (B) L15 attenuates p53-dependent cell death. p53 wild-type (WT) or p53-null $\left(p 53^{-/-}\right)$HCT116 cells were incubated with $40 \mu \mathrm{M} \mathrm{L} 15$ for $4 \mathrm{~h}$ before administration of $100 \mu \mathrm{M} 5$-FU for an additional $20 \mathrm{~h}$ of incubation. Untreated (WT and $p 53^{-/-}$) and treated $\left(\mathrm{WT}+\mathrm{L} 15\right.$ and $\left.p 53^{-/-}+\mathrm{L} 15\right)$ cells were subjected to PI staining. The subG1 cell population was counted and plotted. Data shown are average $\pm \mathrm{SD}$ for three independent experiments. $\left({ }^{\star}\right) P=$ 0.018 (WT vs. WT + L15, Student's $t$-test). (C) L15 provides a p53-dependent selection advantage for cells following DNA damage. p53 wild-type (WT) or p53-null $\left(p 53^{-/-}\right)$ HCT116 cells were transfected with 20 $\mu \mathrm{M}$ fluorescein-conjugated L15 or F15 (FAM-L15 and FAM-F15) $4 \mathrm{~h}$ before administration of $170 \mu \mathrm{M}$ etoposide (ETO), and viable cells (PI-negative) were assessed by FACS analysis 1 or $2 \mathrm{~d}$ later. The percentage of $\mathrm{FAM}^{+}$viable cells was assessed at each time point and treatment condition and normalized to the percentage of $\mathrm{FAM}^{+}$ cells prior to etoposide treatment. The right panel shows the fold increase of $\mathrm{FAM}^{+}$viable cells in etoposide-treated samples compared with untreated samples. Data shown are average \pm SD for three independent experiments. A representative FACS analysis (L15 and WT, $24 \mathrm{~h}$ ) is shown in the left panel.

a closed loop by direct interaction between $5^{\prime}$ - and $3^{\prime}$-UTR sequences in the absence of protein factors as a mechanism of controlling efficiency of translation initiation /Guo et al. 2001). The data herein provide an example of regulating mammalian protein translation by formation of a dsRNA structure involving base-pairing between a 5 '- and a $3^{\prime}$-UTR to regulate translation of a discrete mRNA. Mathematical modeling suggests that these interactions occur in p53 mRNA in a wide variety of species and are not limited to human p53. It seems likely that the translation of other eukaryotic gene products will be found to use similar regulatory mechanisms.

In addition to the insights gained into novel mechanisms involved in the regulation of mammalian protein translation and into p53 induction after DNA damage, these results have identified a novel approach to regulating p53 protein levels in cells. Cellular introduction of small oligonucleotides that would disrupt this base-pairing blocks the binding of RPL26 protein to p53 mRNA and reduces p53 induction following exposure to a variety of different DNA-damaging agents. Blunting p53 induction with these oligonucleotides results in increased cell survival following the toxic exposures. Oligonucleotides of sufficiently short length were identified that are able to enter into cells without transfection and are able to blunt p53 induction simply by addition to cultured cells, thus providing a small molecule reagent capable of modulating p53 induction.

Although the induction of p53 protein after DNA damage and other stresses appears to be an important 
mechanism for limiting tumor development, there is a downside associated with p53 induction; namely, associated tissue toxicity (Gudkov and Komarova 2003). Toxicities such as bone marrow suppression and gastrointestinal injury seen with radiation therapy or chemotherapy for cancer or associated with accidental toxic exposures could theoretically be ameliorated by reducing p53 induction. For example, lethal total body irradiation fails to kill mice lacking p53 genes (Levine 1997; Westphal et al. 1998). It is easy to envision the use of such inhibitors to protect from tissue toxicity following accidental exposures to dangerous chemicals or radiation, but, for use in cancer therapies, one would likely only consider using p53 inhibitors to protect normal tissues during therapy for a p53 mutant tumor. Since a high percentage of human tumors contain mutant p53 (Levine 1997), this could still have broad applications. A theoretical concern for blunting p53 induction in such settings might be the possibility of enhanced secondary tumors, but recent data suggest that restoration of p53 function to premalignant or malignant cells is sufficient to provide anti-tumor effects (Martins et al. 2006; Kastan 2007; Ventura et al. 2007; Xue et al. 2007). Since p53 function would only be transiently inhibited in this proposed setting, cancer promotion would be less of a concern. A small molecule, pifithrin, has been reported previously to block p53-dependent transcriptional activation and apoptosis (Komarov et al. 1999), but this agent does not block p53 induction, its molecular mechanism has not been elucidated, and it appears to have some off-target effects (Sohn et al. 2009).

Hypoxia and oxidative stress also induce p53 /Giaccia and Kastan 1998), and blunting p53 induction could reduce tissue damage in settings of hypoxia reperfusion injury, such as a heart attack or stroke. Additional settings where transiently blunting p53 induction would be clinically useful are also conceivable. It is also noted that blunting p53 induction in cultured cells could be a useful tool in research settings, as it might permit growth of cells in cultured systems that are typically difficult to grow because of "culture shock" (Sherr and DePinho 2000). In the experiments reported here, we already demonstrated that one small molecule, L15, can blunt p53 induction and enhance cell survival after chemotherapy exposure following simple addition to cultured cells. The generation of oligonucleotides targeting this p53 structure with improved stability or ability to enter cells, or the identification of small molecules that can block this specific process regulated by RPL26 and sequence-specific RNA interactions, could provide additional useful research tools and clinical reagents. In vivo testing in murine or other model systems will require the identification of the optimal interactive RNA sequence and oligonucleotide inhibitor specific for the given species. As evidenced by the critical importance of the last 3 bases in this particular 21-base human sequence, the critical interactive sequence in any given species may not be immediately obvious from mathematical modeling. Identification of the relevant sequences in other species, however, will be important for preclinical, proof-of-principle tests of targeting this pathway.

\section{Materials and methods}

Cell culture, transfection, and cell death/protection assays

MCF-7 (p53-competent), H1299 (p53-null), HCT116 wild-type, or HCT116 p53 $3^{-/-}$cells were maintained in DMEM plus $10 \%$ fetal bovine serum (FBS). Plasmids and oligonucleotides were transfected into cells using Lipofectamine 2000 (Invitrogen) and Lipofectamine RNAi MAX (Invitrogen). Cell death was assessed by a propidium iodide (PI) staining assay adapted from Yu and Little (1998). Briefly, $4 \mathrm{~h}$ post-incubation with oligonucleotides, HCT116 wild-type or HCT116 p53 $3^{-/}$cells were exposed to $100 \mu \mathrm{M} 5$-FU for 20 h. Cells were harvested, fixed with $100 \%$ cold methanol, and incubated with $10 \mu \mathrm{g} / \mathrm{mL}$ PI plus $250 \mu \mathrm{g} / \mathrm{mL}$ RNase A solution for $30 \mathrm{~min}$ at room temperature before FACS analysis. In cell protection assays, $4 \mathrm{~h}$ post-transfection with the indicated fluorescein (FAM)-conjugated oligonucleotides, HCT116 wild-type or HCT116 p53 ${ }^{-/-}$cells were exposed to $170 \mu \mathrm{M}$ etoposide (Bedford Laboratories) for the indicated periods of time. Cells were then harvested, washed once with PBS, and resuspended in $10 \mu \mathrm{g} / \mathrm{mL} \mathrm{PI} / \mathrm{PBS}$ solution before FACS analysis.

\section{Plasmids, oligonucleotides, and protein}

p53 and its mutants were constructed in a pLPCX vector (Takagi et al. 2005). GFP-RPL26 and Flag-RPL26 were constructed in pEGFP-C3 and pCMV-Flag vectors, respectively. Luciferase reporter constructs were based on a pGL3ctrl vector (Promega). Oligonucleotides used in this study were synthesized at the Hartwell Center of the St. Jude Children's Research Hospital. The sequences of the oligonucleotides were summarized in Supplemental Table 2. Recombinant RPL26 (amino acids 45145) protein was purchased from Abnova.

LNA-modified DNA oligonucleotides (ODN) were purchased from Exiqon. The sequences of L15-LNA and F15-LNA are $+\mathrm{GAC}+\mathrm{ACG}+\mathrm{CTT}+\mathrm{CCC}+\mathrm{TGG}$ and $\mathrm{GG}+\mathrm{TGA}+\mathrm{CAC}+\mathrm{GCT}+\mathrm{TCC}$ $+\mathrm{C}$ respectively. " + " indicates the location of the modified bases.

\section{In vitro RNA synthesis}

Capped p53 mRNA was transcribed in vitro using the mMESSAGE mMACHINE kit (Ambion) followed by a poly(A) tailing kit (Ambion) to add a poly(A) tail modification. The synthesized mRNA was further purified through a MEGAClear column (Ambion) and was quantified using Nanodrop. RNA without modification (RNA-EMSA and RNase digestion assays) was synthesized using the MEGAscript High-Yield Transcription kit (Ambion). All synthesized RNA was purified by the MEGAclear kit (Ambion) or gel purification (http://www.ambion.com).

\section{Dual-luciferase assay}

Luciferase assays were performed by using the dual-luciferase reporter assay system (Promega) according to the manual provided by the manufacturer. Briefly, MCF-7 cells were cotransfected with $4 \mu \mathrm{g}$ of Flag-RPL26, $100 \mathrm{ng}$ of $-145 \mathrm{pGl3ctrl}{ }^{+/-} 3^{\prime}$ UTR (wild-type or mutated 145-base 5'-UTR, luciferase coding sequence, with or without $3^{\prime}$-UTR of human p53 mRNA), and 27 ng of pRL-TK. Twenty-four hours post-transfection, cell lysates were prepared and subjected to the reporter assay according to the manual instructions.

\section{Immunoblot and IP-RT-PCR}

Cell lysates were prepared by a freeze/thaw followed by incubation in RIPA buffer for $30 \mathrm{~min}$ on ice, and supernatants were 
analyzed by immunoblot analysis. Protein samples $(20 \mu \mathrm{g})$ were denatured in an equal volume of SDS sample buffer, separated by $4 \%-12 \%$ SDS-PAGE, and transferred to nitrocellulose membrane. The blots were probed with primary antibody against p53 (DO-1; Santa Cruz Biotechnology), GFP (FL; Santa Cruz Biotechnology), RPL26 (Bethyl Laboratories, Inc.), or Actin (Sigma). Primary antibody binding was detected by incubating with horseradish peroxidase (HRP)-conjugated anti-rabbit, anti-mouse secondary antibody, and further enhanced chemiluminescent visualization (ECL) system (Amersham Biosciences). IP-RT-PCR was performed as described previously in Takagi et al. (2005). Real-time RT-PCR was performed using the $7900 \mathrm{HT}$ sequence detection system and TaqMan One-Step PCR MasterMix Reagents kit (ABI). The primer/TaqMan probe set for human p53 was Hs00153340_m1 (20× mix) (ABI) or Hs00153349_m1. Hs00153340_ml spans exon 1 and exon 2 of human p53 mRNA, and Hs00153349_m1 spans exons 9 and 10. Human 18S rRNA $(20 \times)$ (ABI) was used as an internal control. Total RNA extracted from MCF-7 cells was used for a standard curve. The reaction was performed with $50 \mathrm{ng}$ of total RNA in triplicate reactions in a $30-\mu \mathrm{L}$ volume containing $2 \times$ p53 primer/probe and $1 \times 18 \mathrm{~S}$ rRNA primer/probe. Cycling conditions were $10 \mathrm{~min}$ at $25^{\circ} \mathrm{C}, 30 \mathrm{~min}$ at $48^{\circ} \mathrm{C}, 10 \mathrm{~min}$ at $95^{\circ} \mathrm{C}$, and 40 cycles of $15 \mathrm{sec}$ at $95^{\circ} \mathrm{C}$ and $1 \mathrm{~min}$ at $60^{\circ} \mathrm{C}$ for amplification. The results were analyzed by using SDS 2.2 software (ABI). For comparing total human endogenous p53 mRNA levels in cells, the amount of p53 mRNA level was normalized to the internal 18 S rRNA level. For IP-RT-PCR, the absolute amount of human p53 mRNA level was used for analysis.

\section{RNase digestion assay and RNA-EMSA}

In vitro transcribed RNA was 5' end-labeled using the KinaseMax (Ambion) 5' end-labeling kit. Labeled RNA (40-80 ng) was incubated with indicated amounts of oligonucleotides for $30 \mathrm{~min}$ at $30^{\circ} \mathrm{C}$ in $1 \times$ digestion buffer. After these pretreatments, RNase A $(0.1 \mu \mathrm{g} / \mathrm{mL})$ or RNase T1 $(0.1 \mathrm{U} / \mu \mathrm{L})$ (Ambion) was incubated with the reaction mixture for $15 \mathrm{~min}$ at room temperature. After digestion, RNA was precipitated, resuspended, and separated in precast 15\% UREA-TBE PAGE gel (Invitrogen), and the gel was dried for $2 \mathrm{~h}$ at $60^{\circ} \mathrm{C}$ and then subjected to autoradiography. RNAEMSA protocol was adopted from http://www.vaxron.com; the labeled RNA ( $\sim 100$ ng per sample) was incubated with indicated proteins or antibodies for $15 \mathrm{~min}$ at ambient temperature and separated on $3.5 \%$ native PAGE gel, and the gel was then dried for $2 \mathrm{~h}$ at $80^{\circ} \mathrm{C}$ before autoradiography.

\section{RNase V1 partial digestion/primer extension experiment}

Oligonucleotide primer for primer extension and sequencing reaction was $5^{\prime}$ end-labeled using the KinaseMax (Ambion) $5^{\prime}$ end-labeling kit and purified through MEGAClear column (Ambion). One microgram of in vitro synthesized RNA was digested by $10 \times$ or $14 \times$ dilution of stock RNase V1 $(0.1 \mathrm{U} / \mu \mathrm{L})$ for $15 \mathrm{~min}$ at room temperature based on the manufacturer's instructions (Ambion). The reaction was stopped by phenol/ chloroform extraction followed by ethanol precipitation. The pellet of cleaved RNA was dissolved in $10 \mu \mathrm{L}$ of DEPC treated water for primer extension using SuperScript III first strand cDNA synthesis kit (Invitrogen). The primer extension products were concentrated by ethanol precipitation. For orientation of the cleavage products to the sequence, sequencing reactions were performed with the USB Sequenase version 2.0 DNA sequencing kit (Amersham). The template for sequencing was pLPCX plasmid with full-length human p53 cDNA. Both the sequencing products and reverse transcripts were separated in precast 15\% UREA-TBE PAGE gel (Invitrogen) and then transferred to a nylon membrane before autoradiography.

\section{Acknowledgments}

We thank Dr. Jing Ma for advice in mathematical modeling of the p53 mRNA structure. We thank Dr. Richard Williams and members of the Kastan laboratory for helpful comments on the manuscript, and Drs. Chao Niu, Suqing Xie, and Liusheng He for technical assistance. This work was supported by grants from the NIH (R37ES05777 and P30CA21765), and by the American Lebanese Syrian Associated Charities (ALSAC) of St. Jude Children's Research Hospital.

\section{References}

Amrani N, Ghosh S, Mangus DA, Jacobson A. 2008. Translation factors promote the formation of two states of the closedloop mRNP. Nature 453: 1276-1280.

Ashcroft M, Vousden KH. 1999. Regulation of p53 stability. Oncogene 18: 7637-7643.

Edgil D, Harris E. 2006. End-to-end communication in the modulation of translation by mammalian RNA viruses. Virus Res 119: 43-51.

Franch T, Gultyaev AP, Gerdes K. 1997. Programmed cell death by hok/sok of plasmid R1: Processing at the hok mRNA 3 '-end triggers structural rearrangements that allow translation and antisense RNA binding. J Mol Biol 273: 38-51.

Fu L, Benchimol S. 1997. Participation of the human p53 3'UTR in translational repression and activation following $\gamma$-irradiation. EMBO J 16: 4117-4125.

Giaccia AJ, Kastan MB. 1998. The complexity of p53 modulation: Emerging patterns from divergent signals. Genes Dev 12: $2973-2983$.

Gray NK, Hentze MW. 1994. Regulation of protein synthesis by mRNA structure. Mol Biol Rep 19: 195-200.

Grivna ST, Pyhtila B, Lin H. 2006a. MIWI associates with translational machinery and PIWI-interacting RNAs (piRNAs) in regulating spermatogenesis. Proc Natl Acad Sci 103: 1341513420.

Grivna ST, Beyret E, Wang Z, Lin H. 2006b. A novel class of small RNAs in mouse spermatogenic cells. Genes Dev 20: 1709-1714.

Gruber AR, Lorenz R, Bernhart SH, Neubock R, Hofacker IL. 2008. The Vienna RNA websuite. Nucleic Acids Res 36: W70-W74. doi: 10.1093/nar/gkn188.

Gudkov AV, Komarova EA. 2003. The role of p53 in determining sensitivity to radiotherapy. Nat Rev Cancer 3: 117-129.

Guo L, Allen EM, Miller WA. 2001. Base-pairing between untranslated regions facilitates translation of uncapped, nonpolyadenylated viral RNA. Mol Cell 7: 1103-1109.

Haupt Y, Maya R, Kazaz A, Oren M. 1997. Mdm2 promotes the rapid degradation of p53. Nature 387: 296-299.

Hofacker IL. 2004. RNA secondary structure analysis using the Vienna RNA package. Curr Protoc Bioinformatics 4: 12.2.112.2.12.

Honda R, Tanaka H, Yasuda H. 1997. Oncoprotein MDM2 is a ubiquitin ligase E3 for tumor suppressor p53. FEBS Lett 420: $25-27$.

Kastan MB. 2007. Wild-type p53: Tumors can't stand it. Cell 128: $837-840$.

Kastan MB, Bartek J. 2004. Cell-cycle checkpoints and cancer. Nature 432: 316-323.

Komarov PG, Komarova EA, Kondratov RV, Christov-Tselkov K, Coon JS, Chernov MV, Gudkov AV. 1999. A chemical inhibitor 
of p53 that protects mice from the side effects of cancer therapy. Science 285: 1733-1737.

Kubbutat MH, Jones SN, Vousden KH. 1997. Regulation of p53 stability by Mdm2. Nature 387: 299-303.

Kuersten S, Goodwin EB. 2003. The power of the 3' UTR: Translational control and development. Nat Rev Genet 4: 626-637.

Levine AJ. 1997. p53, the cellular gatekeeper for growth and division. Cell 88: 323-331.

Levine AJ, Oren M. 2009. The first 30 years of p53: Growing ever more complex. Nat Rev Cancer 9: 749-758.

Malkin D, Li FP, Strong LC, Fraumeni JF Jr, Nelson CE, Kim DH, Kassel J, Gryka MA, Bischoff FZ, Tainsky MA. 1990. Germ line p53 mutations in a familial syndrome of breast cancer, sarcomas, and other neoplasms. Science 250: 12331238.

Martins CP, Brown-Swigart L, Evan GI. 2006. Modeling the therapeutic efficacy of p53 restoration in tumors. Cell 127: $1323-1334$.

Mazan-Mamczarz K, Galban S, Lopez de Silanes I, Martindale JL, Atasoy U, Keene JD, Gorospe M. 2003. RNA-binding protein HuR enhances p53 translation in response to ultraviolet light irradiation. Proc Natl Acad Sci 100:83548359.

Melefors O, Hentze MW. 1993. Translational regulation by mRNA/protein interactions in eukaryotic cells: Ferritin and beyond. Bioessays 15: 85-90.

Michael D, Oren M. 2003. The p53-Mdm2 module and the ubiquitin system. Semin Cancer Biol 13: 49-58.

Mosner J, Mummenbrauer T, Bauer C, Sczakiel G, Grosse F, Deppert W. 1995. Negative feedback regulation of wild-type p53 biosynthesis. EMBO J 14: 4442-4449.

Ofir-Rosenfeld Y, Boggs K, Michael D, Kastan MB, Oren M. 2008. Mdm2 regulates p53 mRNA translation through inhibitory interactions with ribosomal protein L26. Mol Cell 32: 180-189.

Olivier M, Hollstein M, Hainaut P. 2010. TP53 mutations in human cancers: Origins, consequences, and clinical use. Cold Spring Harb Perspect Biol 2: a001008. doi: 10.1101/ cshperspect.a001008.

Pickering BM, Willis AE. 2005. The implications of structured $5^{\prime}$ untranslated regions on translation and disease. Semin Cell Dev Biol 16: 39-47.

Prives C. 1998. Signaling to p53: Breaking the MDM2-p53 circuit. Cell 95: 5-8.

Sachs AB. 1993. Messenger RNA degradation in eukaryotes. Cell 74: 413-421.

Schumacher B, Hanazawa M, Lee MH, Nayak S, Volkmann K, Hofmann ER, Hengartner M, Schedl T, Gartner A. 2005. Translational repression of C. elegans p53 by GLD-1 regulates DNA damage-induced apoptosis. Cell 120: 357368.

Sherr CJ, DePinho RA. 2000. Cellular senescence: Mitotic clock or culture shock. Cell 102: 407-410.

Sohn D, Graupner V, Neise D, Essmann F, Schulze-Osthoff K, Janicke RU. 2009. Pifithrin- $\alpha$ protects against DNA damageinduced apoptosis downstream of mitochondria independent of p53. Cell Death Differ 16: 869-878.

Sonenberg N, Hinnebusch AG. 2007. New modes of translational control in development, behavior, and disease. Mol Cell 28: 721-729.

Sonenberg N, Hinnebusch AG. 2009. Regulation of translation initiation in eukaryotes: Mechanisms and biological targets. Cell 136: 731-745.

Standart N, Jackson RJ. 1994. Regulation of translation by specific protein/mRNA interactions. Biochimie 76: 867-879.
Takagi M, Absalon MJ, McLure KG, Kastan MB. 2005. Regulation of p53 translation and induction after DNA damage by ribosomal protein L26 and nucleolin. Cell 123: 49-63.

Vasudevan S, Tong Y, Steitz JA. 2007. Switching from repression to activation: MicroRNAs can up-regulate translation. Science 318: 1931-1934.

Ventura A, Kirsch DG, McLaughlin ME, Tuveson DA, Grimm J, Lintault L, Newman J, Reczek EE, Weissleder R, Jacks T. 2007. Restoration of p53 function leads to tumour regression in vivo. Nature 445: 661-665.

Wade M, Wang YV, Wahl GM. 2010. The p53 orchestra: Mdm2 and Mdmx set the tone. Trends Cell Biol 20: 299-309.

Westphal CH, Hoyes KP, Canman CE, Hua X, Kastan MB, Hendry JH, Leder P. 1998. Loss of atm radiosensitizes multiple p53 null tissues. Cancer Res 58: 5637-5639.

Xue W, Zender L, Miething C, Dickins RA, Hernando E, Krizhanovsky V, Cordon-Cardo C, Lowe SW. 2007. Senescence and tumour clearance is triggered by p 53 restoration in murine liver carcinomas. Nature 445: 656-660.

Yu Y, Little JB. 1998. p53 is involved in but not required for ionizing radiation-induced caspase-3 activation and apoptosis in human lymphoblast cell lines. Cancer Res 58: 42774281. 


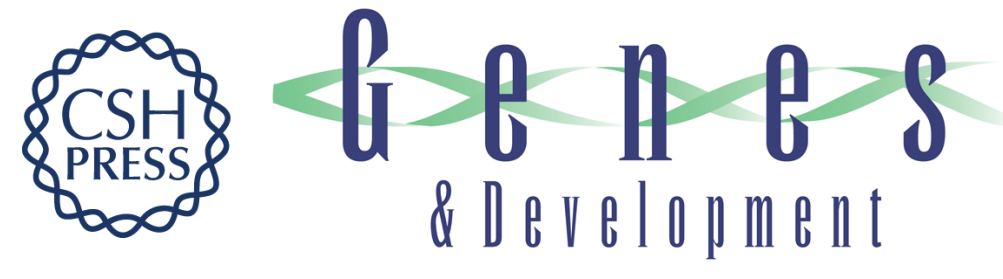

\section{$5^{\prime}-3^{\prime}$-UTR interactions regulate p53 mRNA translation and provide a target for modulating p53 induction after DNA damage}

Jing Chen and Michael B. Kastan

Genes Dev. 2010, 24: originally published online September 13, 2010

Access the most recent version at doi:10.1101/gad.1968910

\section{Supplemental http://genesdev.cshlp.org/content/suppl/2010/09/03/gad.1968910.DC1 \\ Material}

Related Content

Building p53

Tamara Terzian and Guillermina Lozano

Genes Dev. October, 2010 24: 2229-2232

References This article cites 46 articles, 11 of which can be accessed free at:

http://genesdev.cshlp.org/content/24/19/2146.full.html\#ref-list-1

Articles cited in:

http://genesdev.cshlp.org/content/24/19/2146.full.html\#related-urls

License

Email Alerting Receive free email alerts when new articles cite this article - sign up in the box at the top Service right corner of the article or click here.

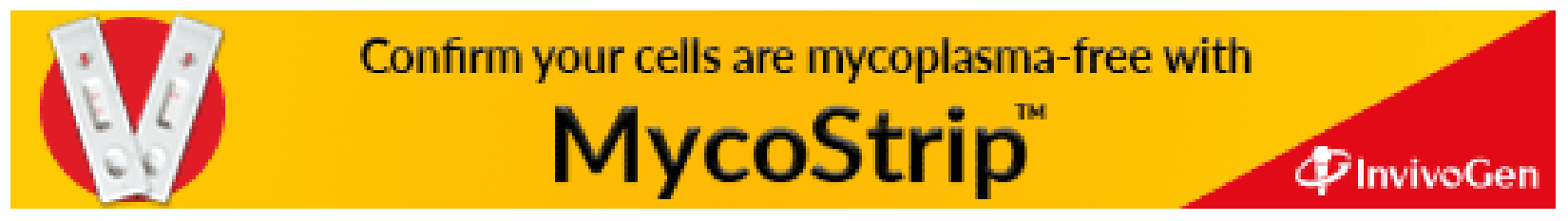

